\title{
Planned Teaching Programme Regarding Basic Life Support in Terms of Knowledge and Skill of Pre-University College Students in a Selected College of Moodbidri, Dakshina Kannada District
}

\author{
Arun Kumar Jindal ${ }^{* 1}$ and Rahul Tiwari ${ }^{2}$ \\ ${ }^{1}$ RP Inderaprastha Institute of Medical Sciences, Karnal, India \\ ${ }^{2}$ Alwar college of nursing, Karnal, India
}

Received: December 01, 2017; Published: December 11, 2017

*Corresponding author: Arun Kumar Jindal, RP Inderaprastha Institute of Medical Sciences, Karnal, India; Email: arunkjindal007@gmail.com

\section{Introduction}

Basic life support is commonly taught to the general public and the new generation as these may be the only ones present in the crucial few minutes before emergency personnel are available. Cardiopulmonary resuscitation is a technique of basic life support for the purpose of oxygenating the brain and heart until appropriate definitive medical treatment can restore the normal heart and ventilatory action. Cardiopulmonary resuscitation, more commonly known as CPR, is a basic life support procedure for people whose heart and lungs have ceased to function effectively. Cardiovascular disease remains the most common cause of death in developed countries and is increasing in number in developing countries. In USA, $48 \%$ of all deaths (1994) were due to cardiovascular disease. In 1997 the death rate was $35 \%$ but $68 \%$ of these deaths occurred before reaching the hospital. In India, in 1994, the annual death rate due to cardiovascular disease was 18\% [1-5]. In 2002 the death rate increased to $26 \%$. National academy of science and national council in 2002 emphasized to rediscover the value of teaching CPR in colleges. In 1998 American Health Association began a large-scale evaluation of CPR in colleges in the US. Experts strongly recommended the development of CPR programmes in colleges to ensure widespread learning of CPR and other basic life support skills, because $70-80 \%$ of cardiac arrest occur at home [5-10].

\section{Objectives of the Study}

a) To assess the knowledge and skill of pre-university college students regarding basic life support.

b) To prepare and conduct planned teaching programme on CPR technique for pre-university college students.

c) To evaluate the effectiveness of planned teaching programme on CPR technique among pre-university college students. d) To find out the significant association of knowledge and skill with selected demographic variables.

\section{Operational Definitions}

a. Effectiveness: The extent to which the planned teaching programme has achieved the desired effect in improving the knowledge and skill on basic life support.

b. Planned teaching programme: It is a systematically organized teaching strategy as basic life support.

c. Basic life support: It is a specific level of pre-hospital medical care provided by trained responders, including emergency medical technicians, in the absence of advanced medical care - demonstration of mouth-to-mouth ventilation and external cardiac compression by one rescue method.

d. Knowledge: It refers to the ability of the sample in giving correct responses to the questions asked as measured by the knowledge questionnaire.

e. Skill: It refers to the proficiency or dexterity that is acquired after the demonstration of the CPR technique on manikin, as measured by the observation checklist.

f. Pre-university college students: Students refers to those studying in the second year science course in selected pre-university college at Moodbidri.

\section{Hypotheses}

$\mathbf{H}_{\mathbf{1}}$ : The mean post-test knowledge score of pre-university college students will be significantly higher than the mean pretest knowledge score regarding CPR technique.

$\mathbf{H}_{2}$ : There will be significant association between knowledge scores of pre-university college students and selected demographic variables. 


\section{Population}

The population for the study comprised of 30 students studying in the selected pre-university college.

\section{Samples}

The sample of the study comprised of 30 students studying in pre-university college.

\section{Sampling Technique}

Simple random technique was used to draw the sample. In this study, the investigator adopted a lottery method to choose 30 students from the sampling frame.

\section{Research Design}

The research design adopted for present study was one group pre-test post-test design adopted in the evaluative research approach for collection and analysis of data. The primary objective of the teaching programme was to impart education on basic life support to the randomly selected sample of 30 pre-university college students assessed in terms of mean gain in knowledge test and mean gain in skill test.

\section{Development of the Tool}

A self-administered questionnaire was prepared to assess the knowledge on basic life support CPR Adult 1 and observation checklist regarding the skill about CPR technique - basic life support adult rescuer method.

\section{Implications}

Curriculum of nursing should prepare the nurses to assess the life-threatening conditions and their management. Adequate classroom teaching and demonstration regarding basic life support will be beneficial. The nursing staff and students can be taught to impart health education to pre-university college students regarding basic life support. Regular education programmes conducted by the nursing personnel, both in the hospital and in the community area will help in the management of life-threatening conditions. The nurse can play an important role in helping the adolescents regarding basic life support. Administration can also take initiatives in imparting health information regarding basic life support through different teaching methods. Individual and group teaching can be arranged for people in the hospitals, schools, colleges and other community settings. There is ample scope for nurses to conduct research in areas like various strategies that can be used in effective management of life-threatening conditions.

\section{Recommendations}

a) A similar study can be conducted on a larger sample for wider generalization. b) A similar study can be conducted with a control group.

c) A comparative study can be carried out on knowledge of basic life support in terms of CPR among university college students.

d) Similar study can be conducted on school children, school teachers, parents, fire force, and traffic policemen.

e) Similar studies could be undertaken using other teaching strategies like video film, film shows or telephonic instruction.

f) A study could be conducted as knowledge regarding basic life support in terms of CPR among nursing students/staff nurse/nursing tutors.

\section{Summary}

Heart action and respiratory effort are absolute requirements in transporting oxygen to the tissues. One of the main organs to suffer from oxygen starvation is the brain, which may sustain damage after 4 minutes and irreversible damage after about seven minutes. The heart also rapidly loses the ability to maintain a normal rhythm. Following cardiac arrest, effective CPR enables enough oxygen to reach the brain to delay brain death and allows the heart to remain responsive to defibrillation attempts. CPR takes a lot of effort and may keep care provides from helping others. The PTP was prepared with the aim of improving the knowledge of pre-university college students related to CPR technique.

\section{References}

1. Aleyamma (1997) A study to assess the effectiveness of teaching of nurse regarding the knowledge of cardiopulmonary resuscitation in a selected hospital. Unpublished M.Sc nursing thesis submitted to Mangalore University, India.

2. (1997) Health care providers' manual for basic life support. American Heart Association, USA.

3. Smeltzer SC (2004) Brunner and Suddarth's textbook of medical surgical nursing. $\left(10^{\text {th }}\right.$ edn) Lippincott Williams and Wilkins, Philadelphia, Pennsylvania, USA.

4. (2000) Handbook on emergency cardiovascular care for healthcare providers. American Heart Association, USA.

5. Basavanthappa BT (2000) Nursing education. Jaypee Brothers, New Delhi, India.

6. Gupta LC, Gupta A (2000) Manual of first aid. Jaypee Brothers, New Delhi, India.

7. Dwarkin GM (1999) Necessity of teaching CPR in colleges. Am J Public Health Aug 72(8): 849-852.

8. (2002) WHO, National Centre of Health Statistics.

9. Stracciolini A, Metzl (2000) Physical medicine and rehabilitation clinics of North America. WB Saunders Company, Philadelphia, USA.

10. (1999) Technical report series. 


$\begin{array}{ll}\text { BIOMEDICAL } & \begin{array}{l}\text { Assets of Publishing with us } \\ \text { RESEARCHES }\end{array} \\ \text { - Global archiving of articles } \\ \text { - Immediate, unrestricted online access }\end{array}$

